National

Academy

of

Sciences

National Research Council

NUCLEAR SCIENCE SERIES

The Radiochemistry

of Magnesium

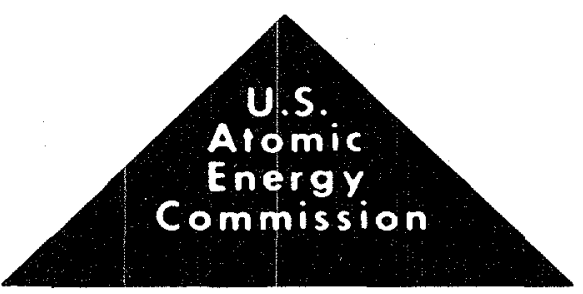




\section{COMMITTEE ON NUCLEAR SCIENCE}

L. F. CURTLBS, Chatrman

National Bureau of 8tandarde
ROBLEY D. EVANS, Vice Chairman

Massachusetts Institute of Technology

J. A. DeJUREN, Secretary

Westinghouse Electric Corporation

C. J. BORKOWSKI

Oak Ridge Nettonal Laboratory

ROBERT G. COCHRAN

Texas Agricultural and Mechanical College

GAMUEL EPSTEDN

Callfornia Institute of Teohnology

U. FANO

National Bureau of Standards

HERBERT GOLDSTEDN

Nuclear Development Corporation of Amertca
J. W. IRVINE, JR. Magsechusette Institute of Technology

E. D. KLEMA

Northwestern University

W. WAYNE METNKE

University of Michigen

J. J. NICKSON

Memorial Hoepltal, New York

ROBERT L. PLATZMAN

Laboratoire de Chlmie Physique

D. M. VAN PATTER

Bartol Research Foundation

\section{LIAISON MEMBERS}

PAUL C. AEBERBOID

Atomlo Energy Commlselon

J. HOW ARD MOMHLLEN

National Solenoe Foundation
CHARLES K. REED

U. 8. Alr Foroe

WILLIAM E. WRIGHT

Offlce of Naval Regearoh

\section{SUBCOMMITTEE ON RADIOCHEMISTRY}

W. WAYNE MELNKE, Chairman Univergity of Michigan

GREGORY R. CHOPPIN

Florida 8tate University

GEORGE A. COWAN

LOS Alamos Sclentlflc Laboratory

ARTHUR W, FAIRHALL

Univergity of Waghington

JEROME HUDIS

Brookhaven National Laboratory

EARL HYDE

Unlverslty of California (Berkeley)
HAROLD KTRBY

Mound Laboratory

GEORGE LEDDICOTTE

Oak RIdge National Laboratory

JULLAN NIELSEN

Hanford Laboratorles

ELLIS P. STEINBERG

Argonne Natlonal Laboratory

PETER C. STEVENSON

University of Callfornia (Livermore)

LEO YAFFE

McGLl University

\section{CONSULTANTS}

NATHAN BALLOU

Centre d'Etude de l'Energle Nucleatre

Mol-Donk, Belgium
JAMES DeVOE

University of Michigan

WLLLAM MARLOW

National Bureau of Standards 


\title{
The Radiochemistry of Magnesium
}

\author{
By A. W. FAIRHALL \\ Department of Chemistry \\ University of Washington \\ Seattle, Washington
}

January 1961

Subcommittee on Radiochemistry

National Academy of Sclences - National Research Council

Printed In USA. Price \$0.60. Avallable from the Office of Technical Services, Department of Commerce, Waehington 25, D. C. 


\section{FOREWORD}

The Subcommittee on Radiochemistry $1 \mathrm{~s}$ one of a number of subcommittees working under the committee on Nuclear sclence within the National Academy of Sciences - Netional Research Council. Its members represent government, industrial, and university laboratorles in the areas of nuclear chemiatry and analytical chemiatry

The Subcommittee has concerned 1tself with those areas of nuclear sclence whlch involve the chemist, such as the collection and distribution of radiochemical procedures, the establishment of speciflcations for radiochemically pure reagents, avallabllity of cyclotron time for service irradiations, the place of radiochemistry in the undergraduate college program, etc.

Th1s serles of monographs has grown out of the need for up-to-date compllations of radiochemical information and procedures. The Subcomittee has endeavored to present a series which will be of maximum use to the working scientist and which contains the latest avallable information. Each monograph collects in one volume the pertinent information required for rediochemical work with an indlvidual element or a sroup of closely related elements.

An expert in the radiochemistry of the particular element has written the monograph, following a standard format developed by the Subcomittee. The Atomic Energy Comission has sponsored the printing of the series.

The Subcommittee is confldent these publications will be useful not only to the radiochemist but also to the research worker in other flelds such as physics, blochemistry or medicine who wishes to use radiocherical techniques to solve a specific problem.

W. Wayne Meinke, Chairman Subcommittee on Radiochemistry 


\section{INTRODUCTION}

Th1s volume which deals with the radiochemistry of magnesium is one of a serles of monographs on radlochemistry of the elements. There 1s included a review of the nuclear and chemical features of particular interest to the radiochemist, a discussion of problems of dissolution of a sample and counting techniques, and finaliy, a collection of radiochemical procedures for the element as found in the literature.

The serlea of monographs will cover all elements for which radiochemical procedures are pertinent. Plans include revision of the monograph periodically as new techniques and procedures warrant. The reader is therefore encouraged to call to the attention of the author any published, or unpublished material on the radiochemistry of magnesium which might be included in a revised version of the monograph. 


\section{CONTENTS}

I. GENERAL REVIEWS OF THE INORGANIC AND ANALYTICAL CHEMISTRY OF MAGNESIUM

II. GENERAL REVIEWS OF THE RADIOCHEMISTRY OF MAGNESIUM ?

III. ISOTOPES OF MAGNESIUM ? 2

IV. REVIEW OF THE CHEMISTRY OF MAGNESIUM OF INTEREST TO RADIOCHEMISTS

1. General Remarks 4

2. Soluble Salts of Magnesium 4

3. Insoluble Salts of Magnegium 5

4. Formation of Complexes by Magnesium 7

5. Separation of Magnesium by Solvent Extraction 7

6. Ion exchange Behavior of Magnesium 8

V. PROCEDURES FOR DISSOLVING THE SAMPLE 11

VI. COUNTING PROCEDURES FOR MAGNESIUM 11

VII. COLLECTION OF DETAIIED RADIOCHEMICAI PROCEDURES FOR MAGNESIUM

Procedure 1. Separation of $\mathrm{Mg}^{28}$ from Tantalum Bombarded with $340 \mathrm{Mev}$ Protons.

Procedure 2. Separation of $\mathrm{Mg}^{28}$ from Lead Bombarded with 0.6 to 3. $0 \mathrm{Bev}$ Protons.

Procedure 3. Purification of $\mathrm{Mg}^{28}$ Tracer Produced in Neutron-. Irradiated Li-Mg Alloy.

Procedure 4. Purification of $\mathrm{Mg}^{28}$ Tracer Produced in NeutronIrradiated Li-Mg Alloy 
Procedure 5. Separation of Carrier-Free $\mathrm{Mg}^{28}$ from High Energy Proton-Bombarded KCl Targets

Procedure 6. Separation of Carrier-Free $\mathrm{Mg}^{28}$ from High Energy Proton-Bombarded NaCl Targets

18

Procedure 7. Activation Analysis for Mg in Blood Cells and

Blood Plasma 


\title{
The Radiochemistry of Magnesium*
}

\author{
A. W. FAIRHALL \\ Department of Chemistry \\ Univergity of Washington, Seattle, Washington
}

\section{GENERAL REVIEWS OF THE INORGANIC AND ANALYTICAL CHEMISTRY OF MAGNESIUM}

\author{
"M agnesium", pp 219-242, Vol. I of The Chemical Elements and. Their \\ Compounds", N.V. Sidgwick, Oxford Univergity Pre日,, London, 1950. \\ "Magnesium", pp 249-397, Vol. IV of "A Comprehensive Treatise on \\ Inorganic and Theoretical Chemistry", J.W. Mellor, Longmans, Green \\ and Co., London, 1923. \\ "Magnesium", Gmelin's Handbuch der Anorganiachen Chemie, System \\ Nr. 27b, 8th Edition, Verlag Chemie G.m.b.H., Berlin, 1939. \\ "Magnesium", Chapter 41, pp 632-645, "Applied Inorganic Analysis", \\ W.F. Hillebrand, G. E. F. Lundell, H.A. Bright and J.I. Hoffman, \\ 2nd Edition, John Wiley and Sons, Inc., New York, 1953. \\ "Magnesium", pp 528-553, Vol. I of "Scott's Standard Methods of \\ Chemical Analysis", N. H. Furman, editor, 5th Edition, D. Van \\ Nostrand Co., Inc., New York, 1939. \\ L.W. Neidrach, A.M. Mitchell and C. J. Rodden, pp 359-363. \\ "Analytical Chemistry of the Manhattan Project", C. J. Rodden, \\ editor-In-chief, McGraw-Hill Book Co., Inc., New York, 1950.
}

This report was prepared at the request of the Subcommittee on Radiochemistry of the Committee on Nuclear Science of the National Research Council as a contribution to a proposed master file on the radiochemistry of the elements. 


\section{GENERAL REVIEWS OF THE RADIOCHEMISTRY OF MAGNESIUM}

"Production and Availability of Magnesium-28", L. G. Stang, N. D. Tucker, A. J. Weiss, and H.O. Banks, Jr., Brookhaven National Laboratory Report BNL 3138, 1956.

"Production of $\mathrm{Mg}^{28}$ in the Pile and Cyclotron at Harwell", C. E. Meligh and G. W. Crockford, Internat. J. Appl. Rad. and Isotopes 1, 299 (1957).

III. ISOTOPES OF MAGNESIUM

The isotopes of magnesium which are known to exist ${ }^{1}$ are tabulated in Table I. They range over the rather narrow mass interval from masg

TABLE I. ISOTOPES OF MAGNESIUM

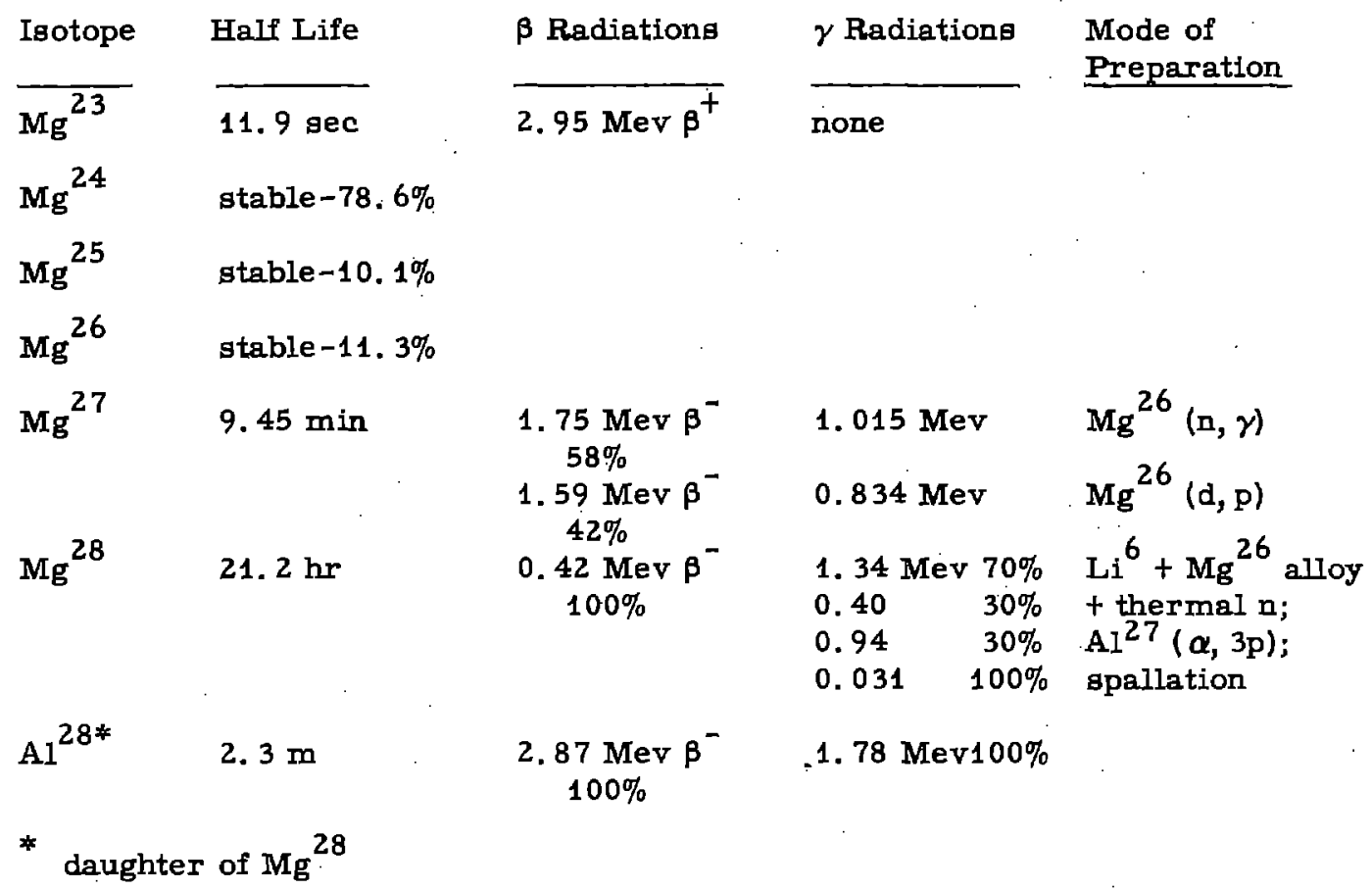

number 23 to 28 . The isotope of mass number 22 has been reported ${ }^{2}$ to have a half-life of 0.13 gecond, but its existence is doubtful. Isotopes of mass numbers 29 and 30 might have long enough half lives to be measureable, but there is no convenient way of synthesizing these nuclides at the present time, consequently their nuclear decay characteristics are unknown. 
The principle radioisotope of magnesium, from the point of view of a tracer, is $\mathrm{Mg}^{28}$. Its half-life of $21.2 \pm 0.1$ hours is long enough for many purposes, but not really as long as one would like. For continued experimentation a given supply of tracer will have decayed to practically nothing in a week or two and a fresh supply must then be procured. The tracer is relatively expensive and this makes for costly experimentation.

There are several methods available for synthesizing $\mathrm{Mg}^{28}$. These include high energy spallation reactions ${ }^{3-11}$ on elements heavier than magnegium, bombardment of magnesium ${ }^{3}$ or aluminum ${ }^{12}$ targets with moderate-energy hellum ions, and by the $\mathrm{Mg}^{26}\left(\mathrm{H}^{3}, \mathrm{p}\right) \mathrm{Mg}^{28}$ reaction. in a nuclear reactor, ${ }^{10,13}$ where the $\mathrm{H}^{3}$ projectiles come from the $\mathrm{Li}^{6}\left(\mathrm{n}, \mathrm{H} \mathrm{f}^{3}\right) \mathrm{He}^{4}$ reaction.

Production of $\mathrm{Mg}^{28}$ by spallation reactions in high energy accelerators has the virtue that the $\mathrm{Mg}^{28}$ can, theoretically at least, be obtained carrier-free. However there are a number of practical drawbacka: the low cross-sections for the apallation reactions leading to $\mathrm{Mg}^{28}$, the formidable radiochemical procedures which would be necessary for a high degree of radiochemical purity, and the difficulty and cost of bombardments in high energy accelerators. Owing to these difficulties, $\mathrm{Mg}^{28}$ is presently made for tracer purposes almost exclusively in nuclear reactors.

Synthesis of $\mathrm{Mg}^{28}$ by neutron irradiation of a lithium-magnesium mixture means that the radioisotope is unavoidably diluted with magnesium. At the present time the sole sommercial supplier of $\mathrm{Mg}^{28}$ in the United States, the Hot Laboratory Division of the Brookhaven National Laboratory, supplies $\mathrm{Mg}^{28}$ at a apecific activity of 50 microcuries of equilibrium $\mathrm{Mg}^{28}-\mathrm{Al}^{28}$ containing not more than $0.1 \mathrm{~g}$ of magnesium. The $\mathrm{Mg}^{28}$ content at time of shipment is normally $50-100$ microcuries to allow for radioactive decay during shipment. The price per 50 microcurie unit at the present time is $\$ 70$, plus a handling charge of $\$ 30$ per shipment. 14 Early in 1961 the Brookhaven Laboratory will begin supplying $\mathbf{M g}^{28}$ which will have approximately a 20-fold higher specific activity. The use of magnesium enriched in $\mathrm{Mg}^{26}$ in the neutron-irradiated lithiummagnesium alloy will be responsible for the increased specific activity. The radioisotope $\mathrm{Mg}^{27}$, with a 9.45 minute half-life, is too shortlived to be of much practical use as a tracer. However, its formation 
by the $(n, \gamma)$ reaction on stable $\mathrm{Mg}^{26}$ means that this radioisotope is potentially useful in activation analysis for magnesium. ${ }^{15,16}$ The low cross section ${ }^{17}$ for absorption of a thermal neutron by $\mathrm{Mg}^{26}, 0.026 \mathrm{barn}$, coupled with the low abundance of $\mathrm{Mg}^{26}$ and the need for speed in separating magnesium from the irradiated sample in a radiochemically pure form, are limitations on the usefulness of this technique.

\section{REVIEW OF THE CHEMISTRY OF MAGNESIUM OF INTEREST TO RADIOCHEMISTS}

\section{General Remarks}

In the opinion of the author, magnesium does not have a welldeveloped radiochemiatry. The reason for this is fairly clear: until the radioisotope $\mathrm{Mg}^{28}$ was discovered ${ }^{3}$ in 1953, the 9.3 minute $\mathrm{Mg}^{27}$ was the longest-1tved magnesium radioisotope which was known and this short a half-life makes $\mathrm{Mg}^{27}$ Impractical as a tracer. During the time that radiochemical techniquea were being developed for the other member of the alkaline earth family, because they possessed auitably long-lived radioisotopes, magnesium was largely neglected.

Since $\mathrm{Mg}^{28}$ became avallable its use has been growing steadily and rapidly, mainly in the field of biological research. ${ }^{18-26}$ in a few instances it has been applied to studies of a chemical nature, ${ }^{27-30}$ with notable success. Considering the ubiquitous nature of magnesium, in the crust of the earth, the oceang, as an important element in chlorophyll, hence of biological systems, and as a metal of commerce, one might imagine that there would be a great need for and interest in a long-lived tracer for so important an element. While the half-life of $\mathrm{Mg}^{28}$ is less than ideal, it is nevertheless a practical tracer for magnesium. It is to be hoped that its usefulness will continue to grow and that it will be applied to many more of the se areas than has been the case until now .

\section{Soluble Salts of Magnesium}

The common salts of magnesium which are freely soluble in water include the acetate, benzoate, bromate, bromide, chlorate, perchlorate, chloride, chromate, citrate, ferrocyanide, iodate, lodide, lactate, permanganate, molybdate, nitrate, sulfate, sulfite and thiosulfate. In addition to these there are numerous other salts which are soluble in acidic solutions or in the presence of ammonium ealts. Examples of the ee include the carbonate and the hydroxide in the presence of ammonium ion, 
and the arsenate and oxalate, which are soluble in acid or in the presence of a high concentration of ammonium salts. In general, magnegium has very few truly insoluble compounds, and even the moderately insoluble ones, such as the fluoride, which is soluble to the extent of $8 \mathrm{mg} / 100 \mathrm{ml}$ of water, are too soluble for the purposes of radiochemical separation, considering the amounts of magnesium carrier which are usually used.

3. Insoluble Salts of Magnesium

There are five compounds of magnesium whtch are sufficiently insoluble under the conditions of their precipitation to make them useful in radiochemical separations of magnesium. These are the hydroxide, when precipitated by strong alkali; $\mathrm{MgNH}_{4} \mathrm{PO}_{4} \cdot 6 \mathrm{H}_{2} \mathrm{O}$, when precipitated by

TABLE II. SPARINGLY SOLUBLE COMPOUNDS OF MAGNESTUM

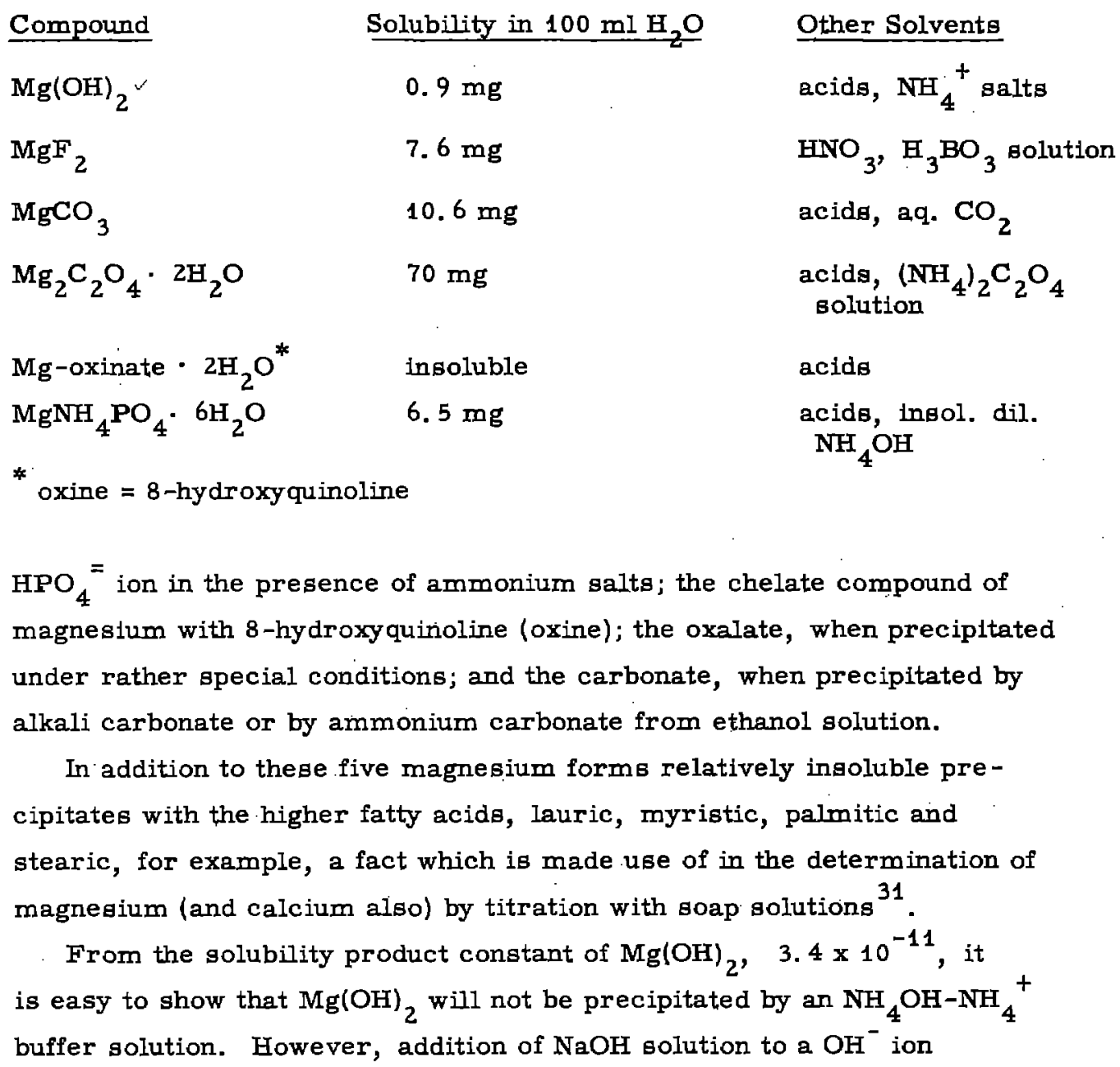


concentration of only $0.001 \mathrm{M}$ will auffice to precipitate macro amounts of magnesium essentially quantitatively. The formation of a radiocolloid by tracer magnesium in strong $\mathrm{NaOH}$ solution has been used in the separation of carrier-free magnestum ${ }^{32}$. Insoluble hydroxides, such as $\mathrm{Fe}(\mathrm{OH})_{3}$ are therefore good carrlers for magnegium when preclpitated from strongly basic solutions.

Precipitation of $\mathrm{MgNH}_{4} \mathrm{PO}_{4} \cdot 6 \mathrm{H}_{2} \mathrm{O}$ is a standard analytical method for magnesium. The precipitate is granular, and therefore easily filtered, and may be ignited to the pyrophosphate, $\mathrm{Mg}_{2} \mathrm{P}_{2} \mathrm{O}_{7}$, for weightng. The precipitation is carried out by adding an excess of $\left(\mathrm{NH}_{4}\right)_{2} \mathrm{HPO}_{4}$ to the acidified solution containing magnesium. The solution is then made alkaline with $\mathrm{NH}_{4} \mathrm{OH}$, cooled, and allowed to stand, preferably for some hours, to permit formation of the precipitate. The precipitate, after filtration, is washed with dilute $\mathrm{NH}_{4} \mathrm{OH}$ to prevent hydrolysis, and subsequent disøolution, of the precipitate.

Precipitation of magnesium by 8-hydroxyquinoline has the virtues that the precipitation is esgentially quantitative and under certain conditions may be precipitated in the presence of strontium and barium without the latter species coprecipitating to an appreciable extent ${ }^{33}$. Calcium coprecipitateg with magnesium but can be dissolved from the precipitate with dilute acetic acid. A better method than this one for separating magnesium from the other alkaline earths is by cation exchange resins (see part 6).

The procedure for precipitation of magnegium with oxine from solutions containing no interfering ions is as follows ${ }^{33}$. The solution containing magnesium is made alkaline with ammonia and the solution is heated to $70-80^{\circ} \mathrm{C}$. A $1 \%$ solution of oxine in $2 \mathrm{~N}$ acetic acid is added slowly until present in slight excess as shown by the yellow color of the solution. After digesting for 10 minutes the precipitate may be filtered, washed with water and dried at $105^{\circ} \mathrm{C}$. The precipitate under these conditions has the formula $\mathrm{Mg}\left(\mathrm{C}_{9} \mathrm{H}_{6} \mathrm{ON}\right)_{2} \cdot 2 \mathrm{H}_{2} \mathrm{O}$ and is 6.98 percent $\mathrm{Mg}$ by weight.

Under rather special conditions magnegium oxalate can be precipitated as a densely crystalline precipitate of $\mathrm{MgC}_{2} \mathrm{O}_{4} \cdot 2 \mathrm{H}_{2} \mathrm{O}$. The recommended procedure $^{34}$ is to start with the magnesium dissolved in $15 \mathrm{ml}$ of water in a $250 \mathrm{ml}$ beaker. Add $75 \mathrm{ml}$ of glacial acetic acid, and when solution is complete add $10 \mathrm{ml}$ of glacial acetic acid containing $1 \mathrm{gram}$ of ammonium 
acetate. Finally add $1.5 \mathrm{ml}$ of ethyl oxalate and stir thoroughly. Cover the beaker with a watch glass, heat the solution to $100^{\circ} \mathrm{C}$ and keep it hot for 2-3 hours after precipitation of magnesium begins. As a precautionary measure, in case the proper temperature has not been maintained, add, 15 minutes before filtration, $5 \mathrm{ml}$ of $85 \%$ acetic acid saturated with ammonium oxalate at room temperature. Filter the precipitate and wash with warm $\left(70-80^{\circ} \mathrm{C}\right) 85 \%$ acetic acid. Dry at $105^{\circ} \mathrm{C}$ to constant weight.

Magnesium is not precipitated by ammonium carbonate from aqueous solutions containing ammonium salts, but does yield a precipitate with alkali carbonate. In the latter cage the precipitate containg a mixture of magnesium carbonate hydrates and the double carbonate with the alkali metal. For gravimetric determination the carbonate is preclpitated with ammonium carbonate from alcohol solution. The procedure ${ }^{35}$ is as follows: saturate with ammonium carbonate a mixture in the proportion by volume of $18 \mathrm{ml} \mathrm{NH}_{4} \mathrm{OH}, 75 \mathrm{ml}$ water and $95 \mathrm{ml}$ of $95 \%$ ethanol. To the magnesium dissolved in a volume of $50 \mathrm{ml}$ add $50 \mathrm{ml}$ of $95 \%$ ethanol and $50 \mathrm{ml}$ of the prepared reagent. Stir for 5 minutes and let the mixture stand for 20 minutes. Filter and Ignite the precipitate to MgO.

4. Formation of Complexes by Magnesium

The small size and double charge on the magnestum ion is conductve to complex formation. The formation of hydrates is a case in point. Most magnesium salts crystallize from aqueous solutions with geveral molecules of water of crystallization. One of the etrongest drying agents known, $\mathrm{MgClO}_{4}$, owes its dehydrating power to the atrong tendency of magnesium to form hydrates.

Numerous chelating agents form complexes with magnesium. The salt of magnesium with 8-hydroxyquinoline has already been mentioned (part 3). Numerous other organic chelating agents have found use in the colorimetric determination of magnestum ${ }^{36}$.

The formation constants for several magnesium complexes are tabulated in Table III.

5. Separation of Magnesium by Solvent Extraction

The anhydrous magnesium halides are readily soluble in a variety of oxygenated organic solvents (alcohols, ketones, ethers) owing to coordination of the magnesium to the oxygen of the solvent. These compounds are not stable in the presence of water, however, owing to the 
much stronger tendency of magnesium to form hydrated complexe日, and solvent extraction of these species from aqueous solution is not possible.

The author was unable to uncover any solvent extraction procedures for magne日ium.

6. Ion Exchange Behavior of Magnesium

TABLE III. FORMATION CONSTANTS FOR SOME MAGNESIUM COMPLEXFS

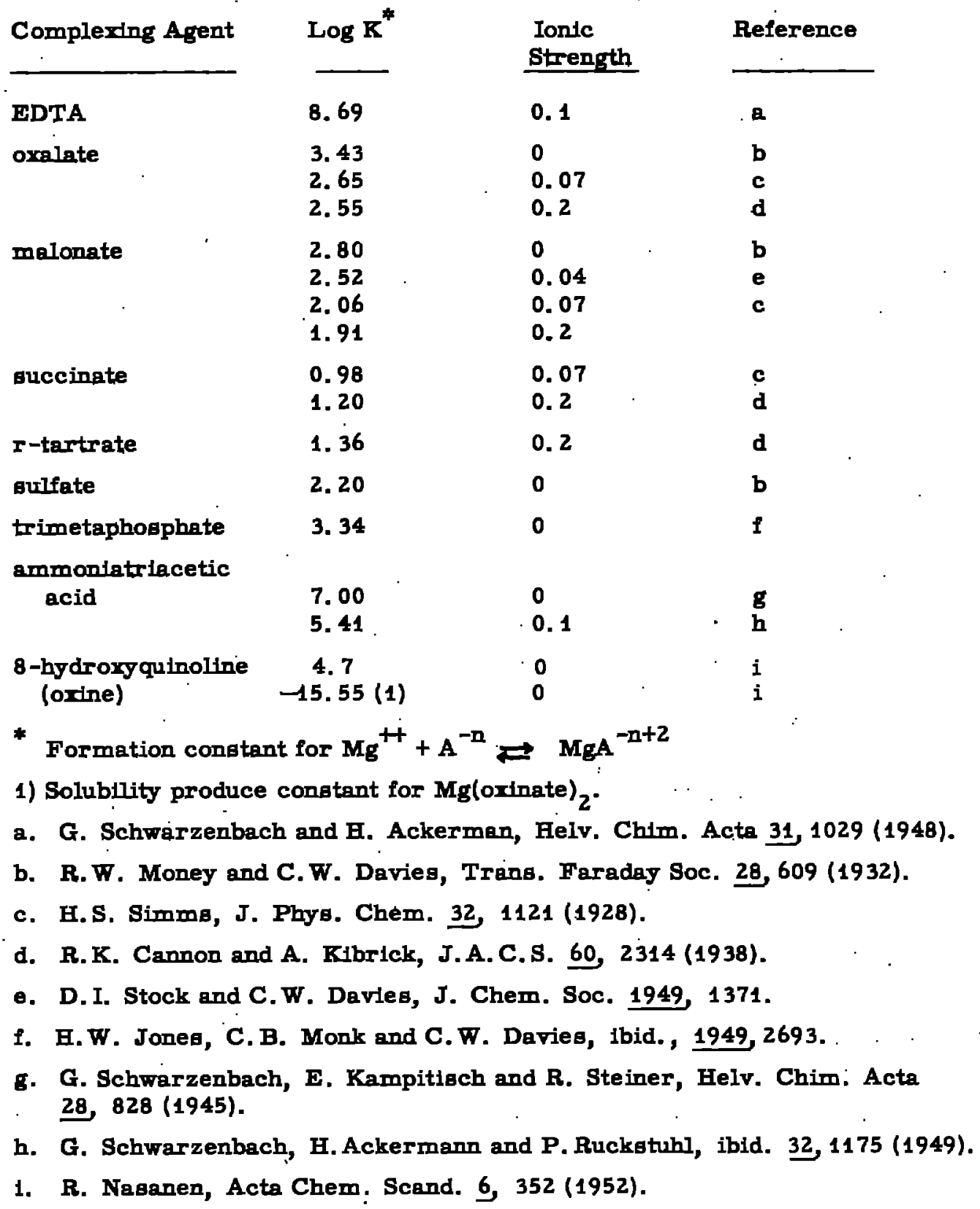


Magnesium is strongly absorbed from solutions of near-neutrality by cation exchange resins. The magnesium may be eluted from the resin by a complexing agent or by acid.

Milton and Grummitt studied the separation of the alkaline earth elements by means of Dowex-50 and the eluting agents ammonium lactate, ammonium citrate or hydrochloric acid. The use of ammonium lactate gave a somewhat cleaner separation of magnesium than was obtained using $\mathrm{HCl}$. However, the ease of recovery of magnesium from the $\mathrm{HCl}$ effluent makes it the more desirable eluting agent. Their results using $\mathrm{HCl}$ are shown in Figure 1. ${ }^{37}$

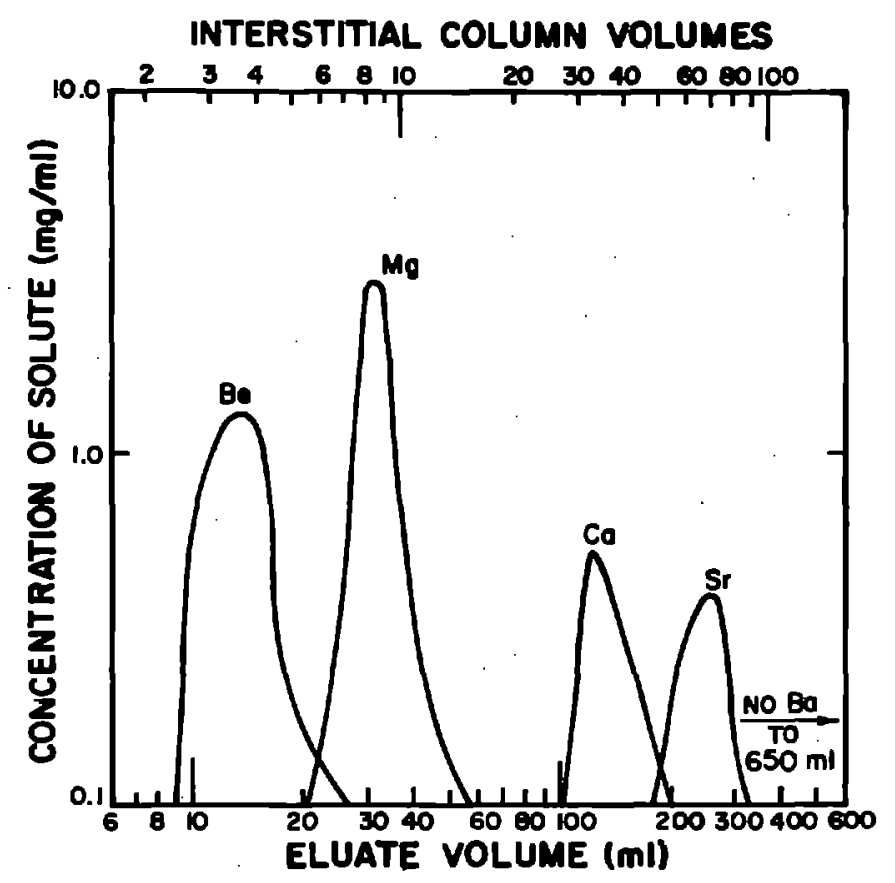

Figure 1. The separation of beryllium, magnesium, calcium, and atrontium by cation exchange using 1. $5 \mathrm{M} \mathrm{HCl}$ eluant. Dowex 50 column $1.1 \times 8 \mathrm{~cm}$, flow rate $1.0 \mathrm{ml} / \mathrm{min}, \mathrm{T}=60^{\circ} \mathrm{C}$. Data of Milton and Grummitt, reference 37.

A similar study of the separation of magnesium from calcium using Dowex 50 and dilute $\mathrm{HC} 1$ as the eluting agent has been reported by Campbell and Kenner. ${ }^{38}$

In the determination of the magneglum content of bone it is necessary 
to remove interfering ions derived from bone which are present along with the magnesium. Breibert, Lee, McCoord and Forbes ${ }^{26}$ have described an ion exchange method for isolating magnesium from bone ash free of phosphorus, sodium and calcium. A typical elution curve for bone ash golution passed through a Dowex 50 column and eluted with $0.7 \mathrm{~N} \mathrm{HC1}$ is shown in Figure 2 .

Anion exchange has also been used to separate magnesium from the

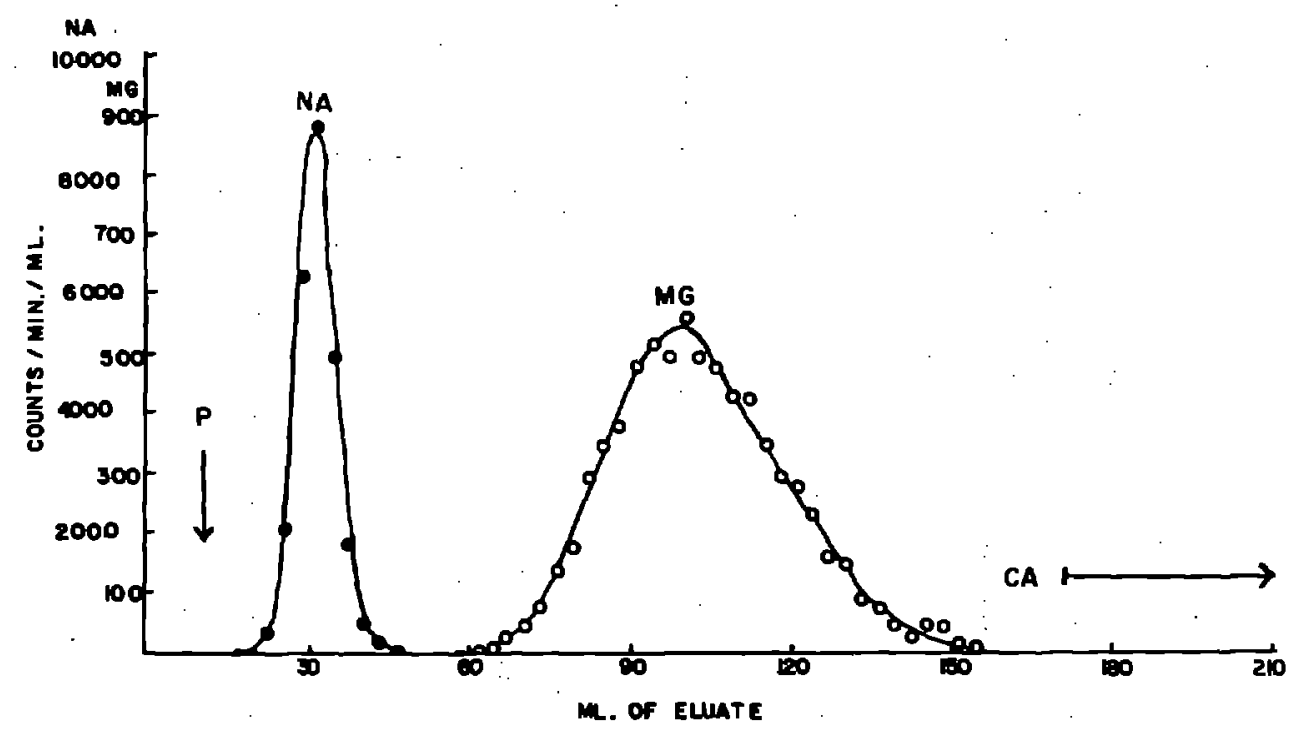

Figure 2. A study of the isolation of magnesium from bone ash solution using tracers for $\mathrm{Mg}$ and $\mathrm{Na}$ and Dowex 50 resin, 50-100 mesh, in a column $0.5 \times 37 \mathrm{~cm}$. An amount of bone ash solution, equivalent to $50-80 \mathrm{mg}$ of dry bone ash; in dilute $\mathrm{HCl}$ was passed through the column. The absorbed lons were then eluted with $0.7 \mathrm{~N}$ $\mathrm{HCl}$ at a flow rate of about $0.7 \mathrm{ml} / \mathrm{min}$. Data of reference 26 .

other members of the alkaline earths. Nelson and Kraus ${ }^{39}$ have used Dowex 1 and ammonium citrate as the complexing agent to effect the separation. The separation of magnesium from beryllium is not perfectly clean, but magnesium is readily separated from the other members of the group.

Kraus and coworkers ${ }^{40}$ have made extensive studies of the anion 
exchange behavior of the metals in chloride solutions. A large number of elementa are absorbed from $\mathrm{HCl}$ solutions by Dowex 1 resin but magnesium is not absorbed from any of these solutions. This fact is ugeful in magnesium separations, for example where iron has been used ag a carrier for magnegium in hydroxide precipitations it may later be removed by absorption on Dowex 1 from strong $\mathrm{HCl}$ solution allowing magnesium to pass through.

Examples of the application of ion exchange to the radiochemical separation of magneaium will be given in the compilation of procedures in part VII.

\section{PROCEDURES FOR DISSOLVING THE SAMPLE}

Since magnesium has only one oxidation state +2 , and since most of its compounds are soluble in acid solution carrler-tracer exchange should be complete in acid solution. It is by no means obvious that carriertracer exchange would not occur in basic solution. However, there are very few materiale which are completely soluble in basic solution. Traces of iron and other impurities which are insoluble and which would tend to occlude radiocolloids of magnesium tracer make carrier-tracer exchange of magnesium problematical under these conditions. Exchange is better carried out in acid solution.

In isolating magnesium from a given material with the aid of magnegium carrier, therefore, it is only necessary to add the carrier and render the material soluble in acid before beginning the separation. This may not always be a trivially easy problem, and several steps may be needed to accomplish it.

Obviously there are a great many materials from which it might conceivably be desired to isolate magnesium, and consequently detailed procedures for dissolving samples are not practical. However, for a few typical examples see Part VII.

\section{COUNTING PROCEDURES FOR MAGNESIUM}

Both radioisotopes of magnesium, $9.45 \mathrm{~m} \mathrm{Mg}^{27}$ and $21.2 \mathrm{~h} \mathrm{Mg}$ decay by $\beta-\gamma$ emission (see Table I), and they may therefore be counted either by $\beta$ counting or by $\gamma$ counting. $\mathrm{Mg}^{28}$ has the added feature that it decays to a 2.3 minute $\mathrm{Al}^{28}$ daughter, which also decays by $\beta$ and $\gamma$ emission. The short half-life of $\mathrm{Al}^{28}$ assures that parent and daughter 
be in secular equilibrium within a few minutes of the time that $\mathrm{Mg}^{28}$ $\therefore$ eparated from $\mathrm{Al}^{28}$ daughters.

For the counting of $\mathrm{Mg}^{27}$ the short half-life suggests that $\gamma$ counting 1d be best. The reason is simply that $\gamma$ counting could be done with fuid sample Isolated as quickly as possible, whereas to $\beta$ count this sies it would be necesaary to prepare the magnesium in a dry, solid n. This would take additional time, and the sample would be weaker Ig to its radioactive decay.

A further consideration which suggeats that $\mathrm{Mg}^{27}$ be detected by $\gamma$ nting is the possibllity of pulee height analysis of the detected $\gamma$ rays. zen becomes possible selectively to count a particular $\gamma$ ray component ch is characteristic of $\mathrm{Mg}^{27}$. This possibility is particularly attractive :re $\mathrm{Mg}^{27}$ is used in neutron activation analysis for magnesium. Here re are numerous possibllities for radioactive contaminants of the lated magnesium fraction. Gamma counting with pulse height analysis es an additional means of identifying the radioactive species being nted, a feature which $\beta$ counting does not have. For the counting of $\mathrm{Mg}^{2 \mathrm{~B}}$ samples it is a matter of taste, or perhaps . :he equipment which is avallable. Beta counting of solld samples would perfectly adequate, although the aimplicity of $\gamma$ counting, from the point vlew of preparation of the counting sample and the relatlve Insensitivity the method to the weight of matertal in the sample, makes the latter attractive method. Of course in $\gamma$ counting of samples it may still necessary to determine the total quantity of magnesium present. is can either be done gravimetrically, or for routine assay one of the lorimetric methoda for magnesium might prove more suitable. The rather energetic $\beta$ rays of both $\mathrm{Mg}^{28}$ and $\mathrm{Al}{ }^{28}$ give agsurance it in the $\beta$ counting of solid samples self-absorption and self-scattering the sample combine to give an apparent specific activity of the sample ich is independent of sample thickness ${ }^{41}$ for samples thicker than about $\mathrm{ng} / \mathrm{cm}^{2}$ up to thicknesses at least as thick as $20 \mathrm{mg} / \mathrm{cm}^{2}$. 
VII. COLLECTION OF DETAILED RADIOCHEMICAL PROCEDURES FOR MAGNESTUM

\section{PROCEDURE 1}

Separation of $\mathrm{Mg}^{28}$ from Tantalum Bombarded with 340 Mev Protons Source - W. E. Nervik, UCRL-2542 (1954)

A procedure for isolating $\mathbf{M g}^{28}$, formed as a spallation product, from a complex mixture of spallation and fission products. The procedure could be adapted without much modification to almost any medium-toheavy element target bombarded with high energy particles.

Step 1. Disgolve the tantalum target in concentrated $\mathrm{HF}-\mathrm{HNO}_{3}$. Add $10 \mathrm{mg} \mathrm{Mg}$ carrier. Add CeII carrier and centrifuge the precipitated rare-earth fluorides from the solution.

Step 2. Make the solution $18 \mathrm{~N}$ in $\mathrm{H}_{2} \mathrm{SO}_{4}$ and extract tantalum by shaking with di-isopropyl ketone.

Step 3. Evaporate the aqueous phase almost to dryness. Dissolve the regidue in $30 \mathrm{ml}$ water and add $3 \mathrm{mg}$ FeII carrier. Precipitate $\mathrm{Fe}(\mathrm{OH})_{3}$ by making the solution basic with $\mathrm{NH}_{4} \mathrm{OH}$. Centrifuge and discard the precipitate.

Step 4. Add $10 \mathrm{mg} \mathrm{Cu}$ carrier and pass in $\mathrm{H}_{3} \mathrm{~S}$. Centrifuge and discard the precipitated sulfides.

Step 5. Adjust the acidity of the solution to $\mathrm{pH} 4$ with acetic acid, add $1 \mathrm{mg}$ each $\mathrm{Ca}$, $\mathrm{Sr}$ and $\mathrm{Ba}$ carriers, followed by $1 \mathrm{ml}$ saturated oxalic acld solution. Centrifuge and discard the precipitated oxalates.

Step 6. Repeat step 5 twice more.

Step 7. Evaporate the solution almost to dryness, add concentrated $\mathrm{HNO}_{3}$ and heat to destroy oxalate. Dilute with water, make the solution basic with $\mathrm{NH}_{4} \mathrm{OH}$ and add excess $\left(\mathrm{NH}_{4}\right)_{2} \mathrm{HPO}_{4}$ to precipitate $\mathrm{Mg}$. Centrifuge and wash the precipitate with dilute $\mathrm{NH}_{4} \mathrm{OH}$.

Step 8.: Dissolve the precipitate in a minimum of concentrated $\mathrm{HCl}$, dilute to about $0.1 \mathrm{M}$ in $\mathrm{HCl}$ and pass through a $2 \mathrm{~mm} \times 10 \mathrm{~cm}$ Dowex 50 column. Wash the column with water and discard the effluent.

Step 9. Strip the Mg absorbed on the column by passing $6 \mathrm{~N} \mathrm{HCI}$ through the column. Repeat the procedure beginning with step 3 .

Step 10. Evaporate the $6 \mathrm{~N} \mathrm{HCl}$ effluent from the second column separation almost to dryness, dilute with water, make the solution basic with 
$\mathrm{NH}_{4} \mathrm{OH}$ and precipitate $\mathrm{Mg}$ with excess $\left(\mathrm{NH}_{4}\right)_{2} \mathrm{HPO}_{4}$. Filter and wash the precipitate twice with dilute $\mathrm{NH}_{4} \mathrm{OH}$ and twice with ethanol. Ignite the precipitate at $1300^{\circ} \mathrm{F}$ and weigh as $\mathrm{Mg}_{2} \mathbf{P}_{2} \mathrm{O}_{7}$.

\section{PROCEDURE 2}

Separation of $\mathrm{Mg}^{28}$ from Lead Bombarded with 0.6 to $3.0 \mathrm{Bev}$ Protons Source - R. L. Wolfgang, E.W. Baker, A. A. Caretto, S. B. Cumming, G. Friedlander and J. Hudis, Phys.. Rev. 103, 394 (1956).

The following procedure, derived from an outline, will separate $\mathbf{M g}^{28}$ from a complex mixture of spallation and fission products. The procedure could be adapted without much modification to almost any mediumto-heavy-element target bombarded with high energy particles.

Step 1. Diseolve the lead target in $6 \mathrm{~N} \mathrm{HNO}_{3}$ and add $10 \mathrm{mg}$ each of $\mathrm{Mg}$ and $\mathbf{P}$ carriers. Boil the solution 5 minutes and then add excess $\mathrm{Zr}$ to precipitate the phosphate. Centrifuge and discard the precipitate.

Step 2. Add Cd and Mo carriers, neutralize excesa acid and precipitate with $\mathrm{H}_{2} \mathrm{~S}$. Centrifuge and discard the precipitated sulfides.

Step 3. Boil the solution to expel $\mathrm{H}_{2} \mathrm{~S}$. Acidify with a few drops concentrated $\mathrm{HCl}$, add 1-2 mg FeIII carrier and make basic with $\mathrm{NH}_{4} \mathrm{OH}$. Centrifuge and discard the precipitate of $\mathrm{Fe}(\mathrm{OH})_{3}$.

Step 4. Repeat the scavenging with 1-2 mg FeIII in ammoniacal solution twice more.

Step 5. Evaporate the eolution to near dryness. Take up in $9 \mathrm{~N} \mathrm{HCl}$ and pass the solution through a $0.5 \times 10 \mathrm{~cm}$ column of Dowex 1 anion exchange resin. Ringe the column with $9 \mathrm{~N} \mathrm{HCl}$.

Step 6. Adjust the acidity of the effluent firom the column to $0.3 \mathrm{M}$ (note 1). Add $10 \mathrm{mg} \mathrm{Cu}$ carrier and precipitate with $\mathrm{H}_{2} \mathrm{~S}$. Centrifuge and discard the precipitate.

Step 7. Boil the solution to expel $\mathrm{H}_{2} \mathrm{~S}$. Add 1-2 mg Fell carrier and make the solution basic with $\mathrm{NH}_{4} \mathrm{OH}$. Centrifuge the precipitate.

Step 8. Evaporate the solution to dryness, add 2-3 $\mathrm{ml}$ of $\mathrm{HNO}_{3}$ and fume to dryness once more to remove ammonium salts. Dissolve the residue in $10 \mathrm{ml}$ of water and add to the solution $10 \mathrm{ml}$ of $95 \%$ ethanol. Preclpitate the magnesium by adding $10 \mathrm{ml}$ of a reagent made by combining 
in the proportion by volume of 18 parts $\mathrm{NH}_{4} \mathrm{OH}, 75$ parts of water and 95 parts $95 \%$ ethanol and saturating this mixture with $\left(\mathrm{NH}_{4}\right)_{2} \mathrm{CO}_{3}$. Centrifuge the precipitate of $\mathrm{MgCO}_{3}$.

Step 9. Dissolve the $\mathrm{MgCO}_{3}$ in a minimum of concentrated HCl. Add $10 \mathrm{mg}$ each $\mathrm{Ba}$ and $\mathrm{Sr}$ carriers. Evaporate the solution to 2-3 $\mathrm{ml}$. Add 10 parts of fuming $\mathrm{HNO}_{3}$ and chill in an lce bath. Centrifuge and discard the precipitated nitrates of $\mathrm{Ba}$ and $\mathrm{Sr}$. Add more $\mathrm{Ba}$ and Sr carriers and again chill the mixtríre. C'entrifuge and digcard the precipitate.

Step 10. Transfer the fuming $\mathrm{HNO}_{3}$ supernatant solution to an Erlenmeyer flask and evaporate the solution almost to dryness. Take up the residue in water. Add $10 \mathrm{mg}$ of $\mathrm{Ca}$ carrier, make the oolution slightly basic with $\mathrm{NH}_{4} \mathrm{OH}$ and precipitate the $\mathrm{Ca}$ with $\left(\mathrm{NH}_{4}\right)_{2} \mathrm{C}_{2} \mathrm{O}_{4}$. Centrifuge and discard the precipitate.

Step 11. Add more $\mathrm{NH}_{4} \mathrm{OH}$ and precipitate the $\mathrm{Mg}$ with $\left(\mathrm{NH}_{4}\right)_{2} \mathrm{HPO}_{4}$. Filter the precipitate, wash with dilute $\mathrm{NH}_{4} \mathrm{OH}$ and alcohol, dry and count. Ignite to $\mathrm{Mg}_{2} \mathbf{P}_{2} \mathrm{O}_{7}$ for determination of chemical yield.

\section{NOTES}

Note 1. Methyl violet is a convenient indicator for adjusting the acidity of the solution.

\section{PROCEDURE 3}

Purification of $\mathrm{Mg}^{28}$ Tracer Produced in Neutron-Irradiated Li-Mg Alloy Source - C.E. Melieh and G.W. Crockford, Internat. J. Appl. Rad. and Isotopes 1; 299 (1957).

The principal impurities in neutron-irradiated L1-Mg alloy are $\mathrm{Na}^{24}, \mathrm{Zn}^{65}$, $\mathrm{Cu}^{64}$, and $\mathrm{Mn}^{56}$.

Step 1. Dissolve the Li-Mg alloy in dilute HCl. Add $\mathrm{Zn}, \mathrm{Cu}$ and $\mathrm{Mn}$ carriers. Make the solution basic with $\mathrm{NH}_{4} \mathrm{OH}$ and preclpitate with $\mathrm{H}_{2} \mathrm{~S}$. Centrifuge and discard the precipitate.

Step 2. Repeat the $\mathrm{H}_{2} \mathbf{S}$ scavenging with $\mathrm{Zn}, \mathrm{Cu}$ and $\mathrm{Mn}$ carriers twice more. Filter the oupernatant liquid from the last scavenging through a fine porasity filter paper. 


\section{PROCEDURE 3 (Continued)}

3. Make the solution strongly basic with $\mathrm{NaOH}$. Centrifuge the ecipitate and discard the aqueous phese.

4. Dissolve the precipitated $\mathrm{Mg}(\mathrm{OH})_{2}$ in dilute $\mathrm{BCl}$. Reprecipitate e $\mathrm{Mg}$ a second time with $\mathrm{NaOH}$. Centrifuge the precipitated $\mathrm{Mg}$ and scard the aqueous phase. The precipitate of $\mathrm{Mg}(\mathrm{OH})_{2}$ should now : free of radioactive contaminants. (Note 1).

\section{NOTES}

1. The radiochemical purity of the magnesium tracer at this point ill of course depend upon the chemical purity of the L1-Mg alloy which as used.

\section{PROCEDURE 4}

fication of $\mathrm{Mg}^{28}$ Tracer Produced in Neutron-Irradiated Li-Mg Alloy ce - L.G. Stang, Jr., W.D. Tucker, A.J. Weiss, and H. O. Banks, Jr. , Brookhaven National Laboratory Report BNL-3138, 1956.

procedure, used for the production of $\mathrm{Mg}^{28}$ tracer in the United $: 9$, is somewhat different from Procedure 3, whlch is the one used in tt Britain. The procedure takes about 2 hours and the recovery is $95 \%$.

1. Dissolve the foil of Li-Mg alloy in water and centrifuge the esultant precipitate of $\mathrm{Mg}(\mathrm{OH})_{2}$. Discard the aqueous phase and wash le precipitate with ice water.

2. Dissolve the $\mathrm{Mg}(\mathrm{OH})$, precipitate in concentrated $\mathrm{HCl}$, add $\mathrm{F}$ arrier and boil to expel $\mathrm{F}^{18}$.

3. Add $\mathrm{NaCl}$ to the solution and continue to evaporate the solution. dd equal volumes of concentrated $\mathrm{HCl}$ and ethanol, chtll in an ice bath, ad filter the precipitated $\mathrm{NaCl}$.

4. Dilute the filtrate with water and add 2-3 $\mathrm{mg}$ FeIII carrier. Lake the solution just basic to bromcresol green indicator with $\mathrm{NaOH}$. entrifuge and discard the precipitate of $\mathrm{Fe}(\mathrm{OH})_{3}$. 5. Add excess $\mathrm{NaOH}$ to precipitate $\mathrm{Mg}(\mathrm{OH})_{2}$. Chill the solution and entrifuge the precipitate. Discard the aqueoug phase and wash the recipitate twice with ice water. The precipitate may now be disolved in any actd for.further use. (Note 1.) 


\section{PROCEDURE 4 (Continued)}

NOTES

Note-1. The material obtained by this procedure is said to contain a trace of $\mathrm{H}^{3}$ impurity, derived from the $\mathrm{Li}^{6}\left(\mathrm{n}, \mathrm{H}^{3}\right) \mathrm{He} e^{4}$ reaction on the lithium of the target, and very small amounts of $\mathrm{F}^{18}$ and $\mathrm{Fe}^{59}$. The $\mathrm{F}^{18}$ impurity decays with a half-life of 112 minuteg, Fe ${ }^{59}$ with a half-life of 45 days. Of course the chemical purity of the Li-Mg alloy is important in determining what other impurities might be present also.

\section{PROCEDURE 5}

Separation of Carrier-Free $\mathrm{Mg}^{28}$ from High Energy Proton-Bombarded KC1 Targets

Source - C.E. Melish and G. W. Crockford, Internat. J. Appl. Rad. and Isotopes 1, 299 (1957).

$\mathrm{Mg}^{28}$ is produced as. a spallation product along with $\mathrm{F}^{18}, \mathrm{Na}^{24}, \mathrm{St}^{31}$, $\mathbf{P}^{32}, \mathbf{S}^{35}, \mathrm{~K}$ and $\mathrm{Cl}$ activities in bombardments of $\mathrm{KCl}$ targets with protons of energy in excess of $60 \mathrm{Mev}$.

Step 1. Dissolve the target in $10 \% \mathrm{HNO}_{3}$ and boil 5 minutes to oxidize Si, $P$ and $S$ activities. Add several grams of $\mathrm{Na}_{2} \mathrm{HPO}_{4}$ and a few $\mathrm{mg}$ of Feس carrier. Make the solution alkaline with $\mathrm{NH}_{4} \mathrm{OH}$ and centrifuge the precipitate. Discard the aqueous phase.

Step 2. Dissolve the $\mathrm{Fe}(\mathrm{OH})_{3}$, which carrieg the $\mathrm{Mg}^{28}$ tracer, in dilute $\mathrm{HCl}$. Reprecipitate the $\mathrm{Fe}$ and $\mathrm{Mg}^{28}$ tracer by making the solution strongly basic with $\mathrm{NaOH}$. Centrifuge the precipitate and discard the aqueous phase.

Step 3. Dissolve the precipitate in $0.05 \mathrm{~N} \mathrm{HCl}$ and pasg the solution through a column of Zeocarb 225 cation exchange resin (note 1). Wash the column with several volumes of $0.05 \mathrm{~N} \mathrm{HC1}$. Finally strip the Fe and $\mathrm{Mg}^{28}$ tracer from the column with $6 \mathrm{~N}$ HCl. Evaporate this effluent to dryness.

Step 4. Take the reaidue up in $10 \mathrm{~N} \mathrm{HCl}$ and pass the solution through a short column of DeAcidite FF anion exchange resin (note 2). Rinee the column with $10 \mathrm{~N}$ HCl. The effluent, which contains the $\mathrm{Mg}^{28}$ in a carrier-free form, may now be evaporated to dryness for recovery of the tracer. 
PROCEDURE 5 (Continued)

\section{NOTES}

Note 1. Dowex 50 or equivalent American-made cotion exchange resin may be aubstituted for this particular resin,

Note 2. Dowex 1 or equivalent American-made anion-exchange resin may be substituted for this particular resin.

\section{PROCEDURE 6}

Separation of Carrier-Free $\mathrm{Mg}^{28}$ from High Energy Proton-Bombarded NaCl Targets

Source - M. Lindner, Phys. Rev. 91, 642 (1953).

$\mathrm{Mg}^{28}$ tracer is separated carrier-free from other spallation products by a procedure which is somewhat similar to Procedure 5.

Step 1. Dissolve the $\mathrm{NaCl}$ target (note 1) in water. Add about $1 \mathrm{mg}$ FeIII carrier and make the solution basic with $\mathrm{NaOH}$. Centrifuge the precipitate, discarding the solution.

Step 2. Dissolve the precipitate of $\mathrm{Fe}(\mathrm{OH})_{3}$ containing the $\mathrm{Mg}^{28}$ tracer in $6 \mathrm{~N} \mathrm{HCl}$. Add $1 \mathrm{mg}$ phosphoric acid and an amount of $\mathrm{Zr}$ in slight excess of that required for complete precipitation of the phosphate. Centrifuge and discard the precipitate.

Step 3. Make the supernatant solution $10 \mathrm{~N}$ in $\mathrm{HCl}$ and then pars the solution through a short column of Dowex 2 anion exchange resin. Rinse the column with $10 \mathrm{~N} \mathrm{HCl}$.

Step 4. Evaporate the HCl effluent to dryness. Take up the residue in water and pass the solution through a short column of Dowex 50 cation exchange resin. Elute the $\mathrm{Mg}^{28}$ tracer with $0.5 \mathrm{~N} \mathrm{HCl}$.

Step 5. Evaporate to dryness that fraction of the $\mathrm{HCl}$ effluent which contains the $\mathrm{Mg}^{28}$ tracer.

\section{NOTES}

Note 1. The use of $\mathrm{KCl}$ target in place of $\mathrm{NaCl}$ yields about $10 \%$ more $\mathrm{Mg}^{28}$ owing to the formation of $\mathrm{Mg}^{28}$ by apallation of the potassium of the target (cf. Reference 10), but it also introduces more radioactive impurities. For the carrier-free separation of $\mathrm{Mg}^{28}$ from $\mathrm{KCl}$ target see Procedure 5. 


\section{PROCEDURE 7}

Activation Analysis for $\mathrm{Mg}$ in Blood Cells and Blood Plasma

Source-R.A. Schmitt, D.A. Elehy and D. Goghor, General Atomic, (unpublished). Communicated by R.A. Schmitt.

Magnesium, along with zinc, manganses and copper, are determined in blood or blood plasma by neutron activation analysis. Only that portion of the procedure pertaining to magnesium is given.

Step 1. Irradiate about $3 \mathrm{ml}$ of blood or about $3 \mathrm{ml}$ of plasma and $\mathbf{M g}$ standard. Transfer the specimen for irradiation into a 2 dram polyvial (about $7 \mathrm{ml}$ capacity). Rince the specimen tube with about $3 \mathrm{ml}$ conductivity water ( $>8 \times 10^{6}$ ohm resistivity) into the polyvial. Pipette $2 \mathrm{ml}$ of $\mathrm{Mg}$ standard, containing approximately $2 \mathrm{mg}$ of magnesium into a separate $2 \mathrm{dram}$ polyvial. Bring volume of gtandard to volume of blood or plasma specimen. Place in reactor (Note 1), rotate specimen rack at $1 \mathrm{rpm}$ and 1 rradiate at a flux of about $2 \times 10^{12}$ neutrons $/ \mathrm{cm}^{2}$. sec for 20 minutes. Remove aample promptly after irradiation.

Step 2. Transfer the $\mathrm{Mg}$ standard into an unirradiated 2 dram polyvial.

Step 3. Transfer the blood or plasma to a test tube containing $\mathrm{Mg}$ carrier, about $10 \mathrm{mg}$, and carriers for $\mathrm{Cu}, \mathrm{Zn}$ and $\mathrm{Mn}$. Swirl and stir the solution to homogeneity and complete "laking", then let stand for about 5 minutes to ensure complete carrier-tracer exchange.

Step 4. Add 15 drops concentrated $\mathrm{HCl}$ slowly to make about $2 \mathrm{~N}$ and to precipitate blood protein. Stir until all protein has precipitated. Centrifuge and decant the solution.

Step 5. Add about $3 \mathrm{ml} 12 \mathrm{~N} \mathrm{NaOH}$ to precipitate $\mathrm{Mg}(\mathrm{OH})_{2}$. Centrifuge (Note 2).

Step 6. Dissolve the precipitate with 10 drops concentrated $\mathrm{HCl}$. Dilute to about $10 \mathrm{ml}$. Make basic with $3 \mathrm{ml} 12 \mathrm{~N} \mathrm{NaOH}$. Centrifuge and decant the solution.

Step 7. Disgolve the precipitate in 10 drops concentrated $\mathrm{HCl}$. Dilute to $8 \mathrm{ml}$ and add 10 drops $2 \mathrm{M} \mathrm{NH}_{4} \mathrm{Cl}$ solution. Add $6 \mathrm{~N} \mathrm{NH}_{4} \mathrm{OH}$ until $\mathrm{pH}$ paper indicates neutrality and then 3 drops in excess. Heat the solution gently.

Step 8. Add 20 drops saturated $\left(\mathrm{NH}_{4}\right)_{2} \mathrm{~S}$ solution. Swirl for 1 minute to precipitate MnS and CuS. Centrifuge. Decant the solution through a fine porosity filter paper (Note 3). 
Step 9. To the filtrate add $2 \mathrm{ml}$ of $12 \mathrm{~N} \mathrm{NaOH}$ to precipitate $\mathrm{Mg}(\mathrm{OH})_{2}$. Centrifuge and decant the solution.

Step 10. Dissolve the $\mathrm{Mg}(\mathrm{OH})_{2}$ with 6 drops concentrated HCl. Dilute to about $10 \mathrm{ml}$. Add $10 \mathrm{drops} \mathrm{Cu}$ carrier (about $10 \mathrm{mg} / \mathrm{ml}$ ), swirl and add about $5 \mathrm{ml} \mathrm{Mannitol} \mathrm{(} 20 \mathrm{~g} / 100 \mathrm{ml} \mathrm{H}_{2} \mathrm{O}$ ) and 2 drops indicator. Make basic with $12 \mathrm{~N} \mathrm{NaOH}$ and add 5 drops of $12 \mathrm{~N} \mathrm{NaOH}$ in excess to precipitate $\mathrm{Mg}(\mathrm{OH})_{2}$. Centrifuge and diacard the solution.

Step 11. Repeat atep 9.

Step 12. Dissolve the precipitate of $\mathrm{Mg}(\mathrm{OH})_{2}$ in 6 drops concentrated $\mathrm{HCl}$. Dilute to $4 \mathrm{ml}$. Filter through a fine porosity fllter paper into a 2 dram vial. Bring volume to that of the irradiated $\mathrm{Mg}$ standard.

Step 13. Count the $843 \mathrm{kev} \gamma$ ray of $\mathrm{Mg}^{27}$ between $790 \mathrm{kev}$ and $890 \mathrm{kev}$ with a $\gamma$ ray epectrometer.

Step 14. After decay of $\mathrm{Mg}^{27}$, determine the chemical yield by precipitation with 8 hydroxyquinoline after treating the solution with hot ammonium oxalate to remove $\mathrm{Ca}$ as calchum oxalate (Note 4).

\section{NOTES}

Note 1. The authors of this procedure use a TRIGA reactor operating at a power level of $250 \mathrm{kw}$. Separate standards for $\mathrm{Cu}, \mathrm{Mn}$ and $\mathrm{Zn}$ would be irradiated also, if these elements are to be determined.

Note 2. If $\mathrm{Zn}$ 1s to be determined also, this solution is saved for later analysis for $\mathrm{Zn}$.

Note 3. The precipitate may be analyzed separately later for $\mathrm{Cu}$ and $\mathrm{Mn}$, if desired.

Note 4. See Section IV, Part 3 for the procedure for gravimetric determination of $\mathrm{Mg}$ as the oxinate. 


\section{REFERENCES}

1. References to original Hterature may be found in "Tables of Isotopes," D. Strominger, J. M. Hollander, and G. T. Seaborg, Reva. Mod. Phys. 30. No. 2, Part II, April, 1958.

2. H. Tyren and P. A. Tove, Phys. Rev. 96, 773 (1954).

3. R.K. Sheline and N.R. Johnson, Phys. Rev. 89, 520 (1953).

4. M. Lindner, Phya. Rev. 91, 642 (1953); Phys. Rev. 89, 1150 (1953).

5. L. Marquez, Phys. Rev. 90, 330 (1953).

6. J. W. Jones and T.P. Kohman, Phys. Rev. 90, 495 (1953).

7. W. E. Nervik and G.T. Seaborg, Phys. Rev. 97, 1092 (1955).

8. C.G. Heninger and E.O. Wiig, Phys. Rev. 101, 1074 (1956).

9. R. L. Wolfgang, E.W. Baker, A.A. Caretto, J. B. Cumming, G. Frledlander and J. Hudis, Phys. Rev. 103, 394 (1956).

10. C.E. Melish and G.W. Crockford, Internat. J. Appl. Rad. and Isotopes 1, 299 (1957).

11. R.E. Dessy, G.S. Handler, J. H. Wotiz and C.A. Hollingsworth, J.A.C.S. 79,3476 (1957).

12. J. Hudis, J. Inorg. and Nuc. Chem. 4, 237 (1957).

13. L.G. Stang, W.D. Tucker, A.J. Weigs and H.O. Banks, Jr., Brookhaven National Laboratory Report BNL-3138, (1956).

14. 'Processed Isotopes Available From Brookhaven National Laboratory, $1960^{\circ}$, Catalog avaflable from Hot Laboratory Division, Brookhaven National Laboratory, Upton, Long Island, New York.

15. W.W. Meinke, Anal. Chem. 31, 792 (1959).

16. R.A. Schmitt, private communication. cf. Part VII, Procedure 7.

17. W.S. Lyon and N.H. Lazar, Phys. Rev. 101, 1524 (1956).

18. B. A. Barnes and G. L. Brownell, Proc. Second Intl. Conf. Peaceful Uses Atomic Energy, Geneva, 26, 204 (1958).

19. J.L. Brandt, W. Glaser and A. Jones, Metaboliem 7, 355 (1958). 
20. J.L. Brandt and W. Glaser, Proc. Soc. Exp. Biol. Med. 101, 823 (1959).

21. W. Glaser and J. L. Brandt, Am. J. Physiol. 196, 375 (1959).

22. L. Silver, J.S. Robertson and L.K. Dahl, J. Clin. Inves. 39, 420(1960).

23. T.A. Rogers and P.E. Mahan, Proc. Soc. Exp. Biol. Med. 100, 235 (1959); T. A. Rogers, F. L. Haven and P. E. Mahan, J. Nat. Cancer Instit. 25,887 (1960).

24. D. L. Gilbert, J. Gen Physiol. 43, 1103 (1960).

25. I. S. Edelman, P.O.P. Ts'o and J. Vinograd, Biochim. Biophys. Acta 43, 393 (1960).

26. S. Breibert, J.S. Lee, A. McCoord and G. B. Forbea, Proc. Soc. Exp. Biol. Med.

27. R.S. Becker and R. K. Sheline, Arch. Biochem. Biophys. 54, 259 (1955).

28. R. E. Dessy and G.S. Handler, J.A.C.S. 80, 5824 (1958).

29. D.A. Brown and J.P. Wella, Soll Science Soc. America Proc. 22 , 323 (1958).

30. A. H. A. Heyn and H. L. Finston, Anal. Chem. 32, 328 (1960).

31. "Organic Analytical Reagenta", Vol. I, p 73, F.J. Welcher, D. Van Nostrand Co., Inc., New York, 1947.

32. H.R. Haymond, J. Z. Bowers, W. M. Garrison and J. G. Hamilton, J. Chem. Phys. 18, 1119 (1950).

33. "Organic Analytical Reagents" Vol. I, p 271, F.J. Welcher, D. Van Nostrand Co., Inc., New York, 1947.

34. L. Gordon and E. R. Caley, Anal. Chem. 20, 560 (1948).

35. "Applied Inorganic Analysis", p 634, W. F. Hillebrand, G.E.F. Lundell, H.A. Bright and J. I. Hoffman, 2nd edition, John Wiley and Sons, Inc., New York, 1953.

36. See, for example, Reference 33, Vols. III and IV.

37. G. M. Milton and W.E. Grummitt, Can. J. Chem. 35, 541 (1957).

38. D. N. Campbell and C.T. Kenner, Anal. Chem. 26, 560 (1954).

39. F.A. Nelson and K.A. Kraus, J.A.C.S. 77, 801 (1955).

40. For references to a long series of papers on anion exchange geparations of metals see F. Nelson, R.A. Day, Jr. and K. A. Kraus, J. Inorg. Nucl. Chem. 15, 140 (1960). See aløo K. A. Kraus and F. Nelson, Proc. Int. Conf. on Peaceful Uses of Atomic Energy, Geneva, 1955, Paper 837, Vol. 7, 113 (1956).

41. W.E. Nervik and P.C. Stevenson, Nucleonics 10, No. 3, 18 (1952). 